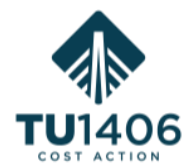

\title{
The impact of different maintenance policies on owners costs: Case Studies from Croatia and the Netherlands
}

\section{Giel Klanker ${ }^{1}$, Irina Stipanovic Oslakovic ${ }^{2}$, Sandra Skaric Palic ${ }^{3}$}

\author{
DOI: https://doi.org/10.5592/CO/BSHM2017.3.4 \\ ${ }^{1}$ Rijkswaterstaat Ministry of Infrastructure and the Environment, Griffioenlaan 23526 LA Utrecht, \\ Netherlands \\ ${ }^{2}$ University of Twente, Faculty of Engineering Technology, Department for Construction Management and \\ Engineering, P.O.Box 217, 7500 AE Enschede, Netherlands \\ ${ }^{3}$ Institut IGH d.d., Janka Rakuse 1, 10000 Zagreb, Croatia \\ E-mails: ${ }^{1}$ giel.klanker@rws.nl, ${ }^{2}$ i.stipanovic@utwente.nl ; ${ }^{3}$ sandra.skaric@igh.hr
}

\begin{abstract}
Optimisation of maintenance planning is an important part of bridge management. The efficiency of condition assessment process is directly influencing the choice of repair and maintenance technique, i.e. measures which have to be undertaken. This paper examines the effect of two opposing maintenance strategies, corrective and preventive maintenance. The condition rating and planned maintenance costs for structural elements of bridges at different ages are compared. In case studies from Croatia and the Netherlands, data from previously performed inspections was compiled in order to correlate age, condition and costs for structural elements. The case studies have been used to assess the impact of different maintenance policies (corrective vs. preventive) on the occurred maintenance costs.
\end{abstract}

Keywords: bridge management system, condition assessment, maintenance options, corrective vs. preventive approach, costs.

\section{Introduction}

Functional and serviceable road infrastructure presents one of the most important predispositions for economic growth of countries around the world. One of the most important and critical parts of road infrastructure are bridges which present a vital link in any roadway network. It is estimated that the ratio of expenses per route $\mathrm{km}$ of bridges is 10 times the average expense per route $\mathrm{km}$ of roads. The length of bridges compared to the whole length of road networks is only approximately $2 \%$ but at the same time they present $30 \%$ value of the whole network (PIARC,1999). During the last decade a new network management philosophy, Asset Management has emerged, which puts the customer - the traffic user - into the centre, and, at the same time, methods to allocate the socio-economic optimal amount of money to each specific asset (roads, bridges, tunnels, lighting, signs, guard rails, etc.). When these developments and statistics are taken into consideration it is easy to understand why, in the past few decades, an increasing number of Bridge Management Systems (BMS) and life cycle maintenance models were developed like for example Branco \& Brito, Frangopol's and Rijkswaterstaat's model (Kaneuji et al. 2006, Airaksinen 2006, Astudillo Pastor et al. 2000, Noortwijk J.M. et al. 2004).

A Bridge Management System (BMS) is defined as a rational and systematic approach to organizing and carrying out all the activities related to managing a network of bridges, including optimizing the selection of maintenance, repair and rehabilitation actions in order to maximize the benefits while minimizing life cycle costs (Hudson et al., 1992). Mainly there are three aspects addressed by BMSs found in literature: condition assessment, modelling future degradation and optimisation of maintenance, repair and rehabilitation decisions and actions. The heart of a BMS however is a database derived from the regular inspection and maintenance activities. The integrity of a BMS is directly related to the quality and accuracy of the bridge inventory and physical condition data obtained through inspections (AASHTO, 1994). Additional information such as the bridge name, location, and construction date are stored in the system.

The BMS can be used as a tool to allow bridge managers to be fully informed about the bridge stock under their control so that they can make informed and optimal decisions about future maintenance and repair activities. 


\section{Maintenance strategies and maintenance planning}

Any BMS is used as a tool as part of a broader bridge management strategy. Depending on the bridge inventory, constraints and societal demands, a road agency will lay out a strategy aiming to achieve optimal results within the limitations posed by the constraints.

Maintenance decisions are based on the deterioration level of an object. Degradation or deterioration of infrastructure is one of the main factor that triggers maintenance. With regard to maintenance planning, two approaches may be applied, a corrective versus a preventive maintenance strategy. In a corrective strategy, maintenance is planned after a certain amount of damage has occurred, whereas a preventive approach aims to plan maintenance so as to prevent unaccepted damages from occurring. In practice, often a combination of both strategies is followed, aiming for an optimal balance between costs and performance, see Figure 1. A good understanding of bridge condition and future degradation is necessary for this optimisation.

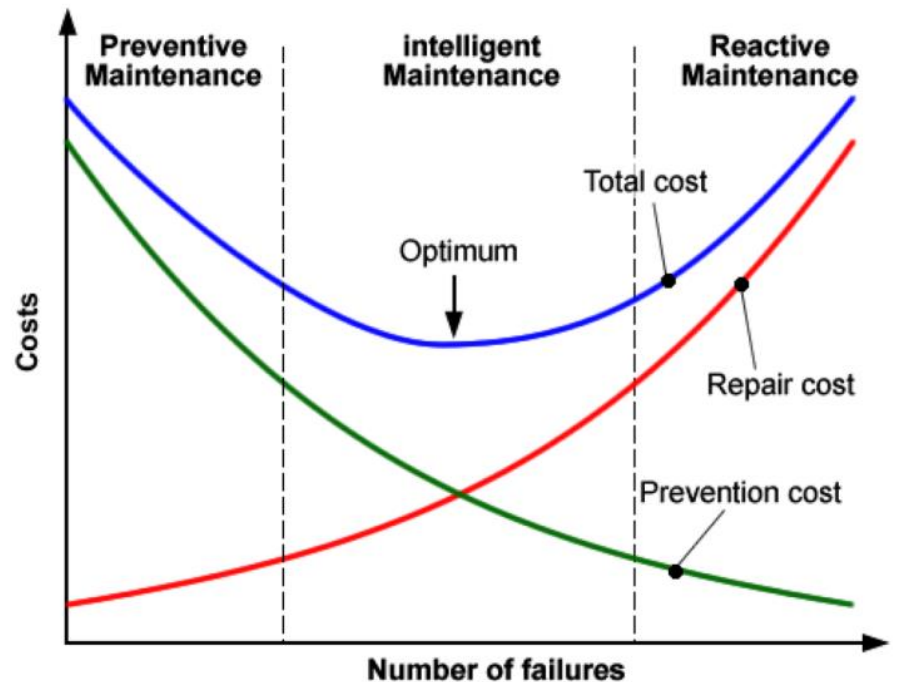

Figure 1: Optimization of Maintenance Costs

Much literature can be found related to condition assessment and modelling future degradation but only few studies have been directed at optimizing the decisions to the maintenance or repair of bridges, especially on the material level (Elbehairy 2007). Frangopol et al. (2001) stated that additional research is required in order to develop a better life cycle so that the costs and benefits can be quantified. Moreover, costs and effects of the interventions should be assessed more accurately based on real data (Bocchini et al., 2010). Best practices call for including all costs incurring through the life of a bridge.

\subsection{Maintenance plan}

A maintenance plan should be based on a decision making system which enables choosing the best repair option considering multiple performance aspects, for example safety, durability, functionality and economy. A first maintenance plan could be made up based on the design of the structure and be periodically updated during the service life based on inspection and maintenance data. Figure 2 presents a general framework for the life cycle of concrete structures, where the strategy of interventions (maintenance, repair, rehabilitation) is consisting of:

1. Defining the set of requirements to be fulfilled by the structure;

2. Performing a technical and economical analysis through the use of requirements and performance indicators, for example by a life-cycle cost analysis (LCCA); and

3. Selecting among the options identified the optimal repair or strengthening method.

Finally, the repair has to be executed and the maintenance needs of the repaired structure have to be established. Although it seems that a life-cycle cost analysis, or LCCA, would be the most suitable methodology for comparing different repair options, a LCCA is very often not feasible because of lack of experience or of reliable data. (Andrade \& Martinez, 2009; CONREPNET 2007, Andrade \& Izquierdo 2005; Frangopol et al. 2001). The process of choosing the best repair option is often expert based. 


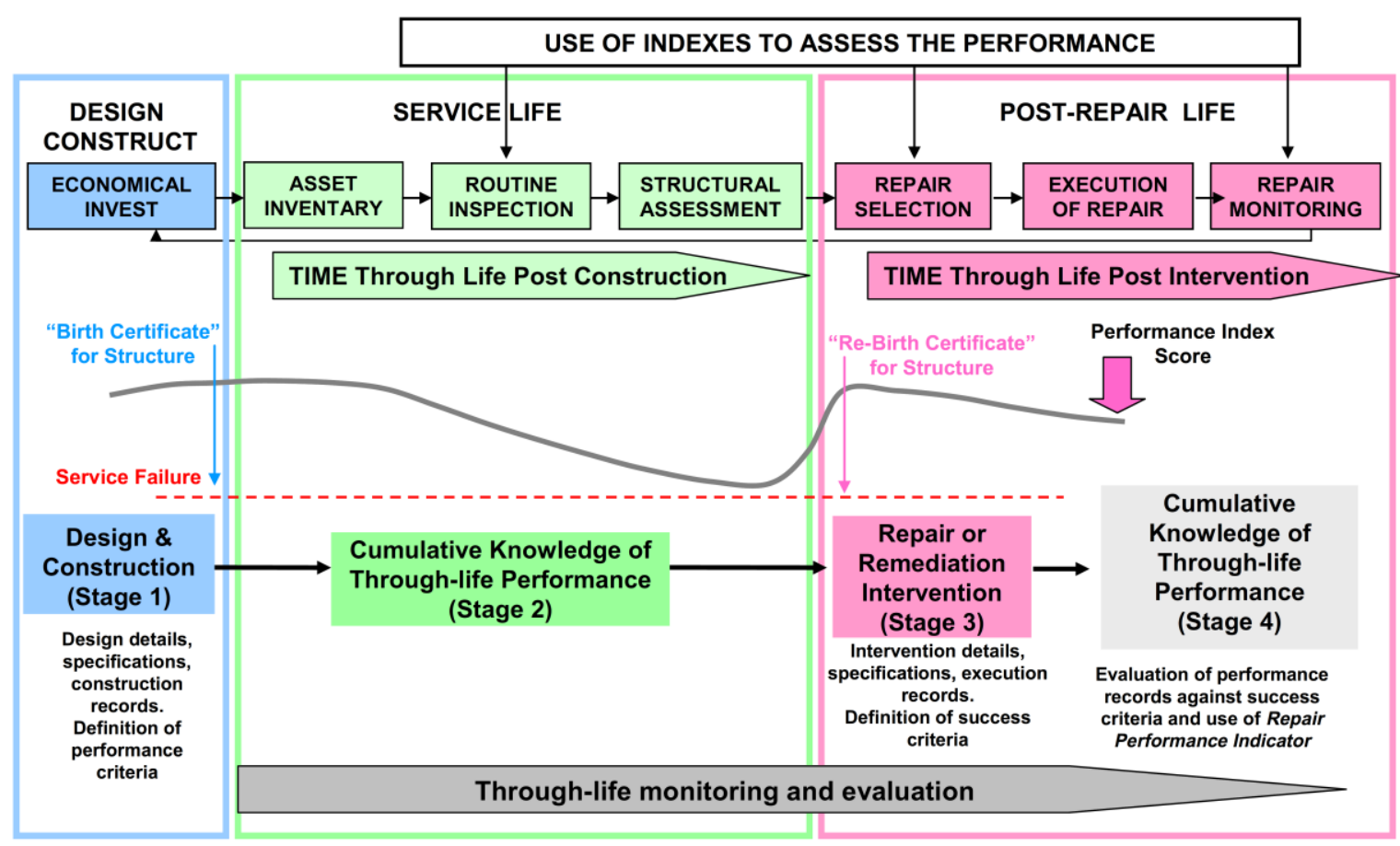

Figure 2: General framework for concrete structure maintenance (Andrade \& Martinez, 2009)

\subsection{Maintenance options}

Common maintenance measures do not need structural design and are generic. They are correlated to the type of elements when these concern the bridge's equipment (eg. joints, bearings) or the type of material when these concern the other elements. More important maintenance measures, like external pre-stress, are correlated to the structural design of the bridge. The European standard EN 1504 gives guidelines for the choice of repair materials and systems that are appropriate for rehabilitation and maintenance of concrete structures. These standards describe the main points of rehabilitation of a damaged concrete structure:

- Assessment of the registered state of a concrete structure

- Determination of the courses of damage

- Determination of the objective of the rehabilitation of a damaged concrete structure

- Choice of relevant principles for rehabilitation of a damaged concrete structure

- Choice of methods for rehabilitation of a damaged concrete structure

- Definition of the properties for repair materials and systems for rehabilitation of a damaged concrete structure or its members

- Specification of requirements for the maintenance that should always follow rehabilitation of a damaged concrete structure or its members.

Table 1: Maintenance strategies

\begin{tabular}{cl}
\hline No & Options for protection and repair \\
\hline 1 & $\begin{array}{l}\text { Do nothing for a certain time } \\
\text { Postpone the repair work, but monitor the degradation process }\end{array}$ \\
\hline 2 & $\begin{array}{l}\text { Re-analysis of structural capacity, possibly leading to downgrading of the } \\
\text { function of the concrete structure }\end{array}$ \\
\hline 3 & $\begin{array}{l}\text { Prevention or reduction of further deterioration, without improvement of the } \\
\text { concrete structure }\end{array}$ \\
\hline 4 & $\begin{array}{l}\text { Improvement, strengthening or refurbishment of all or part of the concrete } \\
\text { structure }\end{array}$ \\
\hline 5 & Reconstruction of part or all of the concrete structure \\
\hline 6 & Demolition of all or part of the concrete structure \\
\hline
\end{tabular}


According to EN1504-9, six different maintenance strategies are possible. Table 1 indicates the strategies that should be evaluated to decide upon the right maintenance for the structure. It should be emphasised that more than one strategy may be relevant and also that each structural part should be given a separate evaluation. Selection of right maintenance strategy and repair method should at least be based on owners requirements, as built documentation, evaluation of the bearing capacity, cost benefit analyses and a detailed condition assessment.

\section{Case study - Croatia}

Croatia has started implementing a bridge management system at Croatian Roads and Highway agency about 20 years ago. Input data for bridge condition are based on visual inspections conducted by specially trained engineers, using procedures and aids defined in the management system, HRMOS (Tenzera et al., 2012). Bridge condition is rated through interpretation of damages that have been identified and registered, then these ratings are combined into a single rating valid for the entire structure. Bridge maintenance activities and costs should be planned by setting priorities and anticipating the future life of the structure. Unfortunately, the introduction of HRMOS did not ensure that the activities related to bridge maintenance are carried out regularly, but on an 'as-needed' basis with inspection and testing undertaken only when structural damage becomes selfevident. This is an example of corrective maintenance policy. To illustrate the grave consequences of neglecting bridge maintenance activities, several cases in the past have shown that if we choose to act only when damage of a bridge structure becomes self-evident, the repairs are not only expensive but very difficult to perform. (Radic et al. 2007, Stipanovic et al. 2008).

In Figure 3 a relation has been established between degradation category and direct cost of repair method, based on the historical data from Croatian case studies (Skaric Palic et al. 2008, Stipanovic Oslakovic et al. 2008). For example cost for category IV and V is the same but risks are different because category V means that stability of element or the whole structure is endangered. The methods and principles used are some of repair methods from standard EN 1504-9:2001. Direct costs included in the analysis present current costs on Croatian market and were collected directly from manufacturers and contractors.

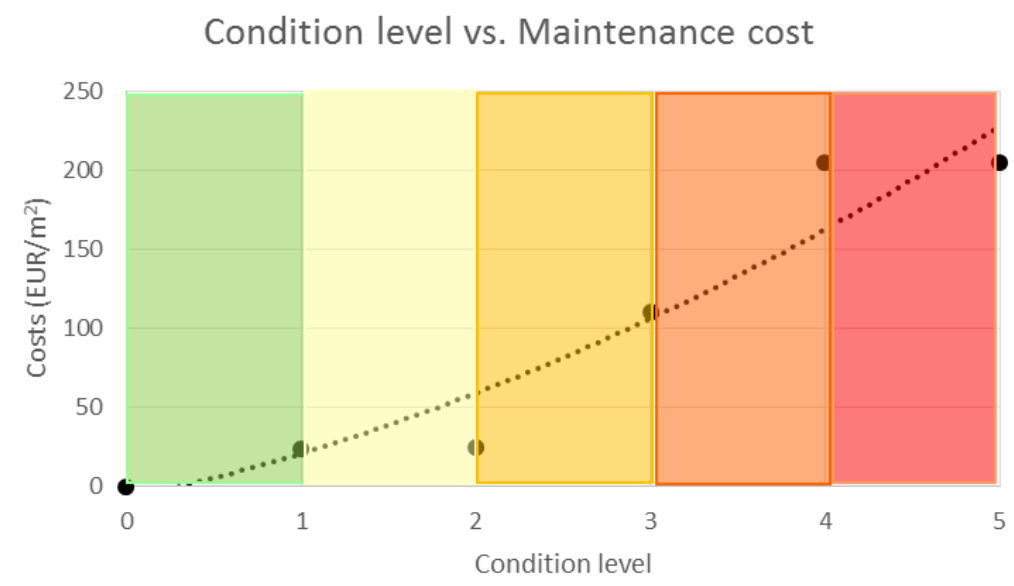

Figure 3: relation between degradation category and direct costs of the repair method

A case study was performed on 12 bridges (viaducts) inspected in 1998 and in 2010. The analysed viaducts are listed in Table 2. Only routine maintenance was performed on viaducts from the year of construction until the final inspection in year 2010. In 1998 and 2010 visual inspection were performed on all structural elements (bridge equipment, substructure and superstructure elements). All defects (delamination, spalling, segregation, corrosion of reinforcement, wet areas, mechanical defects, cracks) were recorded and categorized accordingly. Upon the performed condition assessment a list of repair works needed to bring the structural elements (substructure and superstructure in this analysis) back into their original condition (when constructed) was made with direct costs of all activities.

In Table 2 direct costs of repairs performed in 1998 and 2010 are presented. They are compared and also transformed into the unit value $€ / \mathrm{m}^{2}$. The averaged value of direct repair cost in relation to the age of the bridge is presented in Figure 4. It is obvious that after app. 17 years of usage direct repair costs enhance rapidly. 

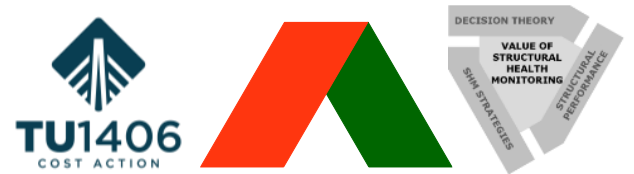

The Value of Structural Health Monitoring for the reliable Bridge Management

Zagreb 2-3 March 2017

Table 2: Analysed viaducts from Croatian case study

\begin{tabular}{|c|c|c|c|c|c|c|}
\hline No & $\begin{array}{l}\text { Year of } \\
\text { construction }\end{array}$ & Length (m) & Technical characteristics & $\begin{array}{c}\text { Bridge } \\
\text { area }\left(\mathrm{m}^{2}\right)\end{array}$ & $\begin{array}{c}\text { Total repair cost } \\
\text { in year } 1998 \\
\left(€ / \mathrm{m}^{2}\right)\end{array}$ & $\begin{array}{l}\text { Total repair } \\
\text { cost in year } \\
2010\left(€ / \mathrm{m}^{2}\right)\end{array}$ \\
\hline 1 & 1988 & $\begin{array}{l}186 \\
\text { (6 spans) }\end{array}$ & \multirow{5}{*}{$\begin{array}{l}4 \text { precast prestressed "T" } \\
\text { girders }(\mathrm{H}=1,70 \mathrm{~m}, \mathrm{~L}=29,85 \mathrm{~m}) \\
+ \text { continuity slab } 24 \mathrm{~cm} \text { (precast } \\
\text { slabs } 6 \mathrm{~cm}+\text { in-situ concrete } 18 \\
\mathrm{~cm}) \\
\text { - Cantilever head beam } \\
\text { - } 2 x O \text { column } \\
\text { - Precast curbs and cornices }\end{array}$} & 1971,6 & 3,7 & 149,0 \\
\hline 2 & 1988 & $\begin{array}{l}189 \\
\text { (6 spans) }\end{array}$ & & 2003,4 & 3,4 & 31,9 \\
\hline 3 & 1988 & $\begin{array}{l}186 \\
\text { (6 spans) }\end{array}$ & & 1971,6 & 3,2 & 68,0 \\
\hline 4 & 1988 & $\begin{array}{l}186 \\
\text { (6 spans) }\end{array}$ & & 1971,6 & 4,5 & 15,2 \\
\hline 5 & 1988 & $\begin{array}{l}127 \\
\text { (4 spans) }\end{array}$ & & 1346,2 & 3,4 & 16,0 \\
\hline 6 & 1988 & $\begin{array}{l}480 \\
\text { (16 spans) }\end{array}$ & $\begin{array}{l}4 \text { precast prestressed "I" girders } \\
(\mathrm{H}=1,70 \mathrm{~m}, \mathrm{~L}=29,85 \mathrm{~m})+ \\
\text { continuity slab } 24 \mathrm{~cm} \text { (precast } \\
\text { slabs } 6 \mathrm{~cm}+\text { in-situ concrete } 18 \\
\mathrm{~cm}) \\
\text { - Cantilever head beam } \\
\text { - } \square \text { column } \\
\text { - Precast curbs and cornice }\end{array}$ & 5088,0 & 6,9 & 27,1 \\
\hline 7 & 1981 & $\begin{array}{l}377 \\
\text { (14 spans) }\end{array}$ & $\begin{array}{l}6 \text { precast prestressed box girders } \\
(\mathrm{H}=1,50 \mathrm{~m}, \mathrm{~L}=29,10 \mathrm{~m}) \\
\text { - Cantilever head beam } \\
2 \mathrm{xO} \text { column }\end{array}$ & 4410,9 & 0,2 & 49,8 \\
\hline 8 & 1981 & $\begin{array}{l}74 \\
(4 \text { spans })\end{array}$ & $\begin{array}{l}6 \text { precast prestressed box girders } \\
(\mathrm{H}=1,10 \mathrm{~m}, \mathrm{~L}=17,30 \mathrm{~m}) \\
\text { - } \quad \text { Cantilever head beam } \\
\text { - } \quad \square \text { column }\end{array}$ & 843,6 & 0,5 & 37,8 \\
\hline 9 & 1981 & $\begin{array}{l}240 \\
\text { (8 spans) }\end{array}$ & $\begin{array}{l}4 \text { precast prestressed "I" girders } \\
(\mathrm{H}=1,86 \mathrm{~m}, \mathrm{~L}=29,75 \mathrm{~m})+ \\
\text { continuity precast slab } 17 \mathrm{~cm} \\
\text { - } \quad \text { Cantilever head beam } \\
\text { - } \quad \text { Octagonal column } \\
\text { - Monolithic pedestrian ways }\end{array}$ & 2760,0 & 18,4 & 152,6 \\
\hline 10 & 1981 & $\begin{array}{l}122 \\
(6 \text { spans })\end{array}$ & $\begin{array}{l}4 \text { precast prestressed "I" girders } \\
\text { + continuity precast slab } \\
\text { - } \quad \text { Cantilever head beam } \\
\text { - } 2 x \square \text { column } \\
\text { - } \quad \text { Precast curbs and cornices }\end{array}$ & 1725,0 & 2,1 & 19,6 \\
\hline 11 & 1981 & $\begin{array}{l}150 \\
(5 \text { spans })\end{array}$ & $\begin{array}{l}4 \text { precast prestressed "I" girders } \\
(\mathrm{H}=1,86 \mathrm{~m}, \mathrm{~L}=29,75 \mathrm{~m})+ \\
\text { continuity precast slab } 17 \mathrm{~cm} \\
\text { - Cantilever head beam } \\
\text { - Octagonal column } \\
\text { - Monolithic pedestrian ways }\end{array}$ & 1342 & 23,9 & 144,2 \\
\hline 12 & 1981 & $\begin{array}{l}50 \\
(1 \text { span })\end{array}$ & $\begin{array}{l}4 \text { precast prestressed "T" girders } \\
(\mathrm{H}=1,70 \mathrm{~m}, \mathrm{~L}=29,85 \mathrm{~m})+ \\
\text { monolithic continuity slab } 17 \\
\mathrm{~cm} \\
\text { Monolithic pedestrian ways }\end{array}$ & 575,0 & 24,3 & 159,3 \\
\hline
\end{tabular}




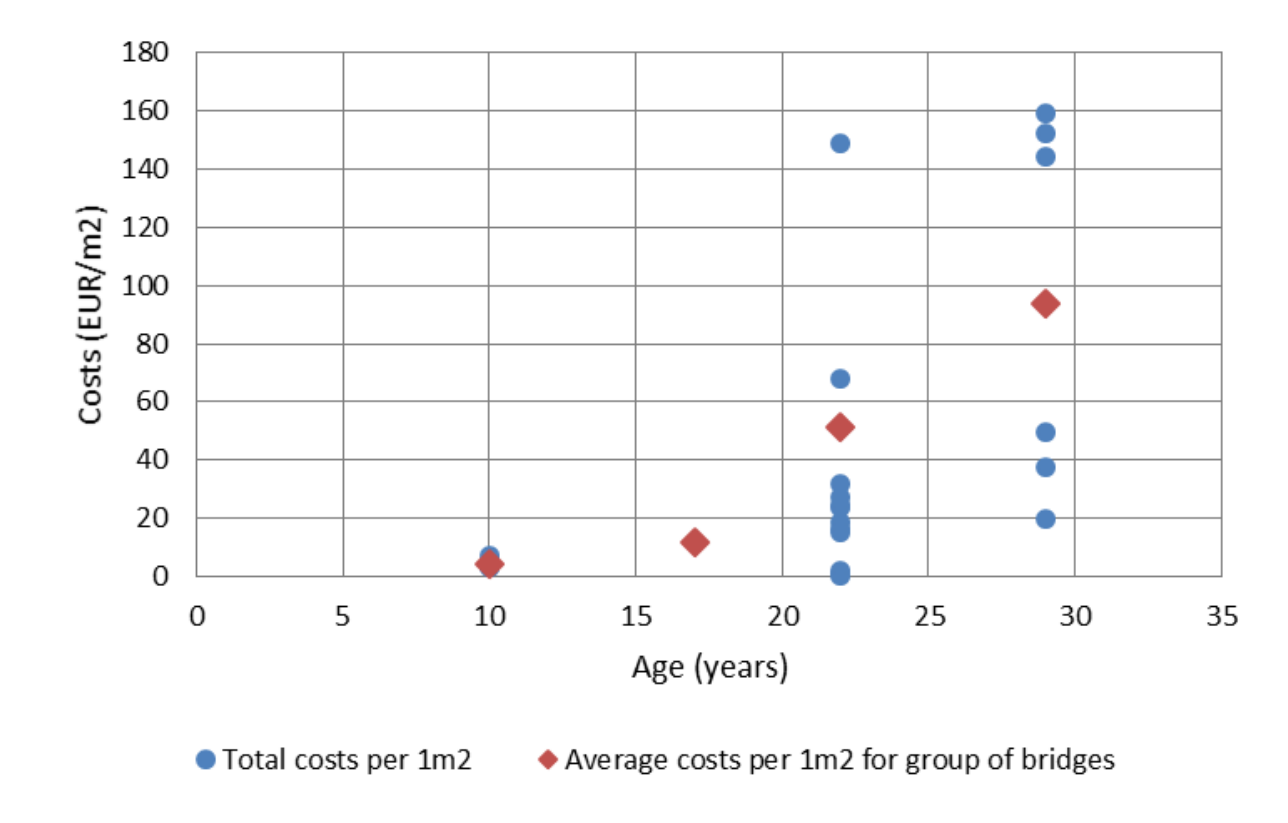

Figure 4: Direct costs established on a case study of 12 viaducts

\section{Case study - the Netherlands}

The maintenance strategy in the Netherlands can be described as a preventive approach. Bridges are inspected on a regular basis and based on the information collected a risks are assessed and maintenance tasks planned to manage and mitigate risks. Maintenance is planned so as to prevent the occurrence of unaccepted risks, the occurrence of unwanted situations is thus prevented. A description of the inspection practice can be found in Bakker et.al. (2012).

During inspections a maintenance strategy is used which states general requirements for different (structural) elements (eg. joints, superstructure, bearings) and materials (eg. concrete, steel). Suggested maintenance options and associated costs are also included in the maintenance strategy. The inspection process is further supported by the DISK Bridge Management System. To rate the condition of bridge elements, a 7 point scale is used (table 4). When an element reaches or approaches a condition rating of 3 a maintenance tasks is to be planned. Note that also at condition 3 requirements are still met. Maintenance tasks are aimed to be preventive.

Table 4. Condition rating in the Netherlands

\begin{tabular}{cl}
\hline $\begin{array}{c}\text { Condition } \\
\text { rating }\end{array}$ & Description \\
\hline 0 & excellent, as new \\
\hline 1 & very good \\
\hline 2 & good \\
\hline 3 & average, risk of meeting requirements \\
\hline 4 & under average, requirements are not meet \\
\hline 5 & poor \\
\hline 6 & bad \\
\hline
\end{tabular}

As a case study, 24 randomly chosen bridges with different periods of construction were analysed (table 5), all part of the main highway network. For each bridge, the results of two inspections (with an interval of circa 6 years) were compared for the main structural elements, with the first inspection between 2008 and 2011 and the second inspection 2014 and 2016. 

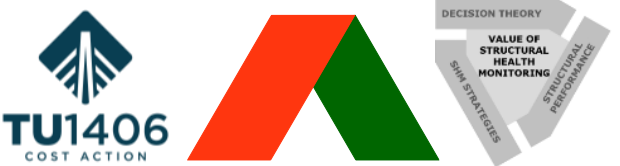

Table 5. Characteristics of the 24 bridges in the case study, incl. costs and condition rating for from two inspections

\begin{tabular}{|c|c|c|c|c|c|c|c|c|c|}
\hline \multirow[b]{2}{*}{$\begin{array}{c}\text { Bridge } \\
\text { No. }\end{array}$} & \multirow[b]{2}{*}{$\begin{array}{c}\text { Year of } \\
\text { Construction }\end{array}$} & \multirow[b]{2}{*}{$\begin{array}{l}\text { Length } \\
\text { (m) }\end{array}$} & \multirow[b]{2}{*}{$\begin{array}{l}\text { Width } \\
\text { (m) }\end{array}$} & \multirow{2}{*}{$\begin{array}{c}\text { Deck } \\
\text { area } \\
\left(\mathbf{m}^{2}\right)\end{array}$} & \multirow[b]{2}{*}{$\begin{array}{c}\text { Object } \\
\text { type }\end{array}$} & \multicolumn{2}{|c|}{ Inspection \#1 } & \multicolumn{2}{|c|}{ Inspection \#2 } \\
\hline & & & & & & $\begin{array}{l}\text { Costs } \\
\left(€ / \mathrm{m}^{2}\right)\end{array}$ & $\begin{array}{c}\text { Condition } \\
\text { Rating }\end{array}$ & $\begin{array}{l}\text { Costs } \\
\left(€ / \mathrm{m}^{2}\right)\end{array}$ & $\begin{array}{c}\text { Condition } \\
\text { Rating }\end{array}$ \\
\hline 1 & 1967 & 49 & 15 & 732 & $\begin{array}{l}\text { Viaduct in } \\
\text { motorway }\end{array}$ & $0,97 \%$ & 3 & $0,26 \%$ & 3 \\
\hline 2 & 1979 & 44 & 15 & 641 & $\begin{array}{l}\text { Viaduct in } \\
\text { motorway }\end{array}$ & $0,00 \%$ & 2 & $0,00 \%$ & 2 \\
\hline 3 & 1979 & 47 & 15 & 692 & $\begin{array}{l}\text { Viaduct in } \\
\text { motorway }\end{array}$ & $0,00 \%$ & 2 & $0,00 \%$ & 2 \\
\hline 4 & 1975 & 48 & 19 & 908 & $\begin{array}{l}\text { Viaduct in } \\
\text { motorway }\end{array}$ & $0,00 \%$ & 2 & $0,08 \%$ & 4 \\
\hline 5 & 1975 & 99 & 15 & 1.496 & Bridge & $0,00 \%$ & 2 & $0,00 \%$ & 2 \\
\hline 6 & 1987 & 40 & 15 & 623 & $\begin{array}{l}\text { Viaduct in } \\
\text { motorway }\end{array}$ & $0,00 \%$ & 3 & $0,00 \%$ & 2 \\
\hline 7 & 1995 & 42 & 15 & 625 & $\begin{array}{l}\text { Viaduct in } \\
\text { motorway }\end{array}$ & $0,00 \%$ & 2 & $0,00 \%$ & 2 \\
\hline 8 & 1987 & 76 & 27 & 2.009 & Bridge & $0,00 \%$ & 2 & $0,00 \%$ & 2 \\
\hline 9 & 1987 & 119 & 14 & 1.637 & Bridge & $0,00 \%$ & 2 & $0,00 \%$ & 2 \\
\hline 10 & 1979 & 29 & 18 & 535 & Bridge & $0,00 \%$ & 2 & $0,00 \%$ & 3 \\
\hline 11 & 1979 & 66 & 20 & 1.344 & $\begin{array}{l}\text { Viaduct in } \\
\text { motorway }\end{array}$ & $0,00 \%$ & 2 & $0,00 \%$ & 2 \\
\hline 12 & 1979 & 66 & 21 & 1.408 & Bridge & $0,00 \%$ & 2 & $0,00 \%$ & 2 \\
\hline 13 & 1995 & 43 & 23 & 970 & $\begin{array}{l}\text { Viaduct in } \\
\text { motorway }\end{array}$ & $0,00 \%$ & 2 & $0,33 \%$ & 2 \\
\hline 14 & 1995 & 166 & 14 & 2.403 & $\begin{array}{l}\text { Viaduct in } \\
\text { motorway }\end{array}$ & $0,00 \%$ & 2 & $0,24 \%$ & 2 \\
\hline 15 & 1995 & 32 & 23 & 725 & Bridge & $0,00 \%$ & 1 & $0,00 \%$ & 2 \\
\hline 16 & 1967 & 36 & 21 & 764 & $\begin{array}{l}\text { Viaduct in } \\
\text { motorway }\end{array}$ & $0,00 \%$ & 2 & $0,06 \%$ & 3 \\
\hline 17 & 1979 & 22 & 23 & 502 & Bridge & $0,00 \%$ & 3 & $0,11 \%$ & 3 \\
\hline 18 & 1967 & 37 & 17 & 611 & Bridge & $0,76 \%$ & 2 & $0,38 \%$ & 3 \\
\hline 19 & 1967 & 112 & 18 & 1.988 & Bridge & $0,00 \%$ & 2 & $0,00 \%$ & 2 \\
\hline 20 & 1967 & 49 & 13 & 653 & $\begin{array}{l}\text { Viaduct in } \\
\text { motorway }\end{array}$ & $0,00 \%$ & 2 & $0,00 \%$ & 2 \\
\hline 21 & 1967 & 44 & 15 & 678 & $\begin{array}{l}\text { Viaduct in } \\
\text { motorway }\end{array}$ & $0,00 \%$ & 2 & $1,13 \%$ & 3 \\
\hline 22 & 1967 & 66 & 17 & 1.093 & $\begin{array}{l}\text { Viaduct in } \\
\text { motorway }\end{array}$ & $0,00 \%$ & 2 & $0,00 \%$ & 2 \\
\hline 23 & 1967 & 35 & 19 & 660 & $\begin{array}{l}\text { Viaduct in } \\
\text { motorway }\end{array}$ & & 2 & $0,00 \%$ & 2 \\
\hline 24 & 1967 & 33 & 17 & 564 & $\begin{array}{l}\text { Viaduct in } \\
\text { motorway }\end{array}$ & & 3 & $0,65 \%$ & 3 \\
\hline
\end{tabular}

First, the condition rating and costs for planned maintenance tasks for the main structural elements were compared for two inspections for each bridge. Note that for most bridges the condition indicated a rather good condition (rating of 1 or 2) in which cases no maintenance tasks were planned. For the last inspection, 8 out of 24 bridges showed a condition worse than 2, for 9 bridges maintenance tasks were planned (table 5).

Secondly, the relation between the age of the bridge at the moment of inspection and both condition and costs for maintenance was analysed. The age of the bridges at the moment of inspection ranged between 13 and 49 years. Most maintenance was planned for bridges constructed over 36 years before the moment of inspection. The exception being three bridges were maintenance was planned after 20 years. 


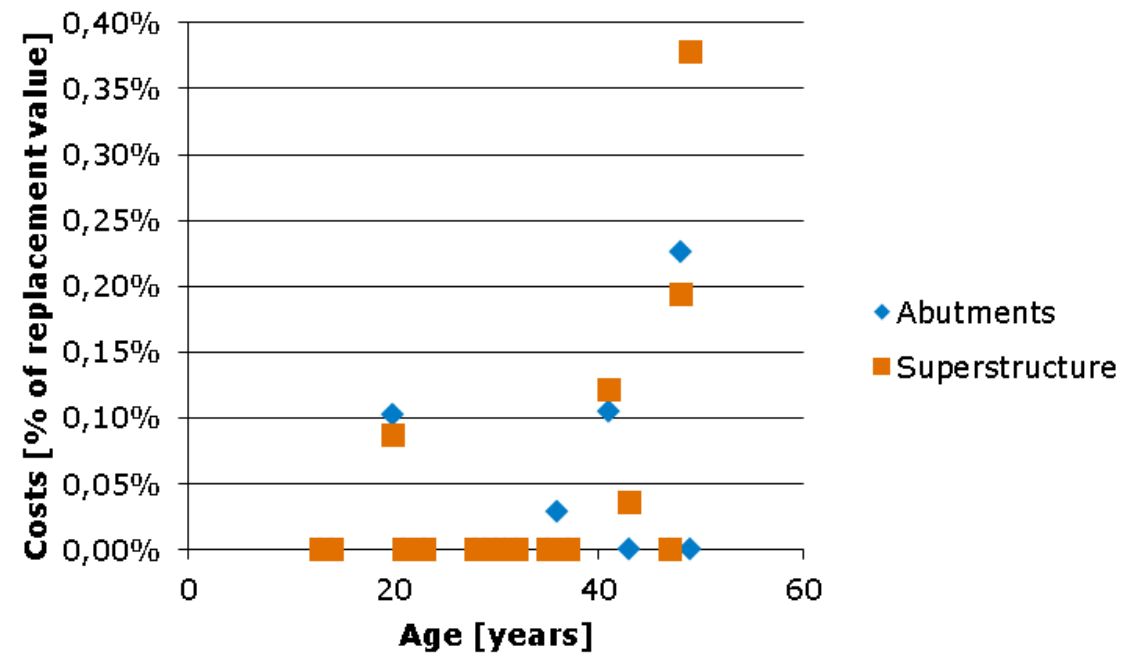

Figure 5. Costs of maintenance tasks relative to bridge age

\section{Discussion and conclusion}

The efficiency of condition assessment process is directly influencing the choice of repair and maintenance technique, i.e. measures which have to be undertaken. This paper examines the effect of two opposing maintenance strategies, corrective and preventive maintenance, from Croatia and the Netherlands respectively. The condition rating and planned maintenance costs for structural elements of bridges at different ages are compared. In case studies from Croatia and the Netherlands, data from previously performed inspections was compiled in order to correlate age, condition and costs for structural elements. Although both cases are limited to only a small number of bridges, it can be argued that there is a relation between the age of the structure and maintenance costs. Also, the increase in maintenance costs appears to be later in the case of the Netherlands than in the Croatian practice. Finally, based on these results if can be concluded that a preventive approach to maintenance planning supported by an inspection procedure will, in the longer term, be more efficient.

\section{Acknowledgements}

This article is based upon the work from COST Action TU1406, Quality specifications for roadway bridges, standardization at a European level (BridgeSpec), supported by COST (European Cooperation in Science and Technology).

\section{References}

AASHTO (1994), "Manual for condition Evaluation of bridges", Second Edition, American Association of State Highway and Transportation Officials, AASHTO, Washington, D.C.

Airaksinen M., Söderqvist M.K. (2006) Bridge life-cycle management in the service of the Finnish Road Administration", Proceedings of the fifth International Workshop on life-cycle cost analysis and design of civil infrastructure systems, 'Life-Cycle cost and performance of civil infrastructure systems', Seoul, Korea, October 16-18, 2006, 71-78.

Andrade C., Izquierdo D. (2005), Benchmarking through an algorithm of repair methods of reinforcement corrosion: The repair index method, Cement and Concrete Composites, Volume 27, Issue 6, 727-733.

Andrade, C., Martínez, I. (2009) Use of indices to assess the performance of existing and repaired concrete structures, Construction and Building Materials 23 (2009) 3012-3019

Astudillo Pastor R., Arrieta Torrealba, Velando Cabanas C. \& Lozano Bruna C. (2000). Bridge Management in Europe (BRIME), PL97-2220, Deliverable D7, Decision on repair/replacement.

Bakker, J. \& Klatter, L. (2012). Risk Based Inspection (RBI) at Rijkswaterstaat. In: Proceedings of the 6th international conference on Bridge Maintenance, Safety and Management, Stresa, Italy

Bocchini P., Frangopol D.M. (2011). A probabilistic computational framework for bridge network optimal maintenance scheduling, Reliability Engineering and System Safety 96, 332-349 

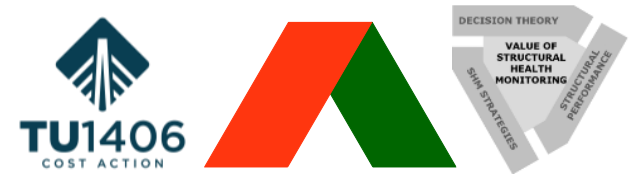

The Value of Structural Health Monitoring for the reliable Bridge Management

Zagreb 2-3 March 2017

CONREPNET (2007) Achieving durable repaired concrete structures: adopting a performance-based intervention strategy. EP77. IHS BRE Press.

Elbehairy H. (2007). Bridge management system with integrated life cycle cost optimization, PhD Thesis, Waterloo, Ontario, Canada.

EN 1504-9: (2001). Products and systems for the protection and repair of concrete structures - Definitions, requirements, quality control and evaluation of conformity - Part 9 General principles for the use of products and systems.

Frangopol, D., Kong, J., and Gharaibeh, E. (2001), "Reliability-Based Life-Cycle Management of Highway Bridges", Journal of Computing in Civil Engineering, ASCE, 15 (1), pp. 27-34

Hudson, R., Carmicheal, R., Hudson, W., and Diaz, M. (1992), Microcomputer Bridge Management System, Journal of Transportation Engineering, ASCE, 119 (1), pp. 59-76

Kaneuji M., Yamamoto N., Watanabe E., Furuta H. (2006). Bridge management system developed for the local governments in Japan, Proceedings of the fifth International Workshop on life-cycle cost analysis and design of civil infrastructure systems, 'Life-Cycle cost and performance of civil infrastructure systems', Seoul, Korea, October 16-18, 2006, 55-68.

Noortwijk Jan M. van, Frangopol D.M. (2004). Two probabilistic life-cycle maintenance models for deteriorating civil infrastructure", Probabilistic Engineering Mechanics 19, 345-359.

PIARC - World Road Association (1999), Reliability-based Assessment of Highway Bridges, PIARC Paris

Radić, J., Šavor, Z., Puž, G., Bleiziffer, J. \& Balažić, A. (2007). Asset Management System for Croatian Motorways. In J. Radić (Ed.), Concrete Structures - Stimulators of Development, fib Symposium Dubrovnik 2007 Proceedings, Zagreb, 881-888.

Škarić Palić S., Stipanović Oslaković I., Mavar K, Balagija A. (2008). „Condition assessment and LCCA of 11 overpasses on Zagreb bypass", Networks for sustainable environment and high quality of life, International Conference and EurekaBuild Event, Dubrovnik, Croatia, pp 141-148.

Stipanović Oslaković, I.; Škarić Palić, S.; Balagija, A.; Mavar, K. (2008). Analysis of durability and life cycle costing of different repair methods applied on 11 city overpasses // Proceedings of 12th International Conference - Structural Faults and Repair.

Stipanovic Oslakovic, I., Bjegovic, D., Radic, J. (2008). Case study: LCC analysis for Krk Bridge, Tailor Made Concrete Structures - Walraven \& Stoelhorst (eds), 2008 Taylor \& Francis Group, London, ISBN 978-0415-47535-8.

Tenžera, D., Puž, G., Radić, J. 2012. Visual inspection in evaluation of bridge condition, GRAĐEVINAR 64 (2012) 9, 717-726. 